\title{
Mary Astell: el camino hacia la felicidad y la armonía interior a través del conocimiento
}

\begin{abstract}
MIRIAM SEGHIRI
Universidad de Málaga

Fecha de recepción: 3 marzo 2007

Fecha de aceptación: 10 mayo 2007

Resumen: Con anteroridad a su tiempo, y un siglo antes de que Mary Wollstonecraft escribiera $A$ Vindication of the Rights of Woman (Una reivindicación de los derechos de la mujer), Mary Astell ya había redactado sendos tratados defendiendo el lugar de la mujer en el mundo y el derecho de ésta a la educación, así como reflexionado sobre la relación entre hombres y mujeres, todos ellos escritos con un estilo claro y fluido. Sin duda, el mejor exponente de su obra es A Serious Proposal to the Ladies for the Advancement of their True and Greatest Interest: By a Lover of Her Sex, o en español, Una propuesta seria para las damas, en beneficio de sus verdaderos y más altos intereses. Por una amante de su sexo (1694). Fue una mente brillante en una época en la que era socialmente inaceptable para una mujer pensar y, aún más, verbalizar ese pensamiento. Percibió esa injusticia y dedicó toda su vida a combatirla con su pluma.
\end{abstract}

Palabras clave: Mary Astell, derechos de las mujeres, feminismo, educación.

Abstract: Hundreds of years before her time, and a century before Mary Wollstonecraft's A Vindication of the Rights of Woman, Mary Astell wrote impassioned treatises on women's position in the world, a woman's right to education, male-female relations, all written in a marvellously fluid style. Undoubtedly, one of her masterpieces is A Serious Proposal to the Ladies for the Advancement of their True and Greatest Interest: By a Lover of Her Sex (1694). She was a brilliant mind in an era when it was socially unacceptable for women to have minds and voices to speak them-she saw an iniquity and she had to speak against it.

Keywords: Mary Astell, Rights of Woman, Feminism, Education.

¿Por qué las mujeres nacen esclavas? ¿No tienen que serlo, si el estar sujeto a la voluntad inconstante, incierta, ignota y arbitraria de los hombres, es la perfecta condición de la esclavitud?

(Astell, 1694)

\section{MARCO HISTÓRICO.}

Durante el siglo XVII, y bajo el impulso dos reformas religiosas, tuvo lugar un aumento considerable de la alfabetización de la población masculina $y$, aunque en menor número, femenina, de la mano, principalmente, de las diferentes órdenes religiosas reformadas, pues 
entendían que era necesaria la instrucción del pueblo para una adecuada evangelización. Sin embargo, a finales del siglo XVII, comenzó a decaer y las familias que antes se esforzaban en ofrecer a sus hijas una educación humanista, ahora sólo las educaban en las labores propias del hogar o, como mucho, a cantar, bailar y tocar algún instrumento. Este declive en la educación de la mujer en Inglaterra se encuentra estrechamente relacionado con los efectos del protestantismo, pues comenzaron a desaparecer instituciones monásticas, centros culturales y artísticos femeninos, centros de estudio de la mujer. A esta situación, se une la controversia sobre si las mujeres tenían o no derecho a la instrucción, pues se pensaba no era apropiado que el género femenino alcanzara el mismo nivel de conocimiento que los hombres ya que el acceso al conocimiento suponía una amenaza a la feminidad que la sociedad patriarcal había ido construyendo. De hecho, era frecuente que las mujeres asiduas a salones literarios fueran objeto de burla y ridiculizaciones, sirva como reflejo de la época obras como Les précieuses ridicules de Molière o La culta latiniparla de Quevedo. De otra parte, otros autores como Poulain de la Barre en su libro La educación de las damas, defendían el derecho de la mujer a la educación. Muchas mujeres nacidas en el siglo XVII como Batshua Makin (1600-1675), Anna Maria van Schurman (1607-1678), Aphra Behn (16401689) o Elisabeth Elstob (1683-1756), por citar sólo algunas de las más relevantes, abogaron por un plan de vida distinto al de la época, pues eran solteras, intelectuales e independientes económicamente. Todas ellas son ejemplos de un modelo de vida que, además, en el caso de Mary Astell alcanzará una propuesta teórica.

\section{BIOGRAFÍA}

Mary Astell nació en 1666 en el seno de una familia burguesa venida a menos de Newcastle (Inglaterra). Fue una mujer reconocida en su tiempo por su ingenio, elocuencia y erudición y creó con su ejemplo un precedente que sería seguido por otras mujeres de la sociedad inglesa: el de la dama instruida que elige vivir sola y en relación con otras mujeres, dedicada al estudio, a la lectura y a la escritura. De hecho, casi un siglo antes de que Mary Wollstonecraft (1759-1797) escribiera $A$ Vindication of the Rights of Woman, 1792, Mary Astell ya había redactado sendos tratados defendiendo el lugar de la mujer en el mundo y el derecho de ésta a la educación, así como reflexionando sobre la relación entre hombres y mujeres, de ahí que se la considere la primera feminista inglesa de reconocido prestigio. Con la temprana muerte de su padre se crió en un hogar fundamentalmente femenino en el que su tío adquirió el papel de preceptor. De este modo, en un momento en que gran parte de las mujeres eran analfabetas, ella recibió una educación humanística, principalmente estudios de filosofía e idiomas 
aunque, por sus escritos, puede inferirse que también le interesaban disciplinas como la teología, las matemáticas, la política, la historia y la literatura clásica. Tuvo una juventud en soledad y dedicada a la lectura que le despertó muchas inquietudes y que la llevó, a la edad de veinte años, a tomar la decisión de mudarse a Londres, donde se instaló en el barrio de Chelsea y se rodeó de un círculo de mujeres, principalmente aristócratas, que, al igual que ella, habían tomado la decisión de permanecer solteras -o de no volver a contraer nupcias, en el caso de que hubieran enviudado-, y que suponían su principal apoyo emocional, intelectual y económico. Precisamente, a muchas de estas amigas dedicó alguna de sus obras como, por ejemplo, a Lady Elizabeth Montague a quien dedicó la edición de 1694 de una de sus obras más emblemáticas, su Propuesta seria para las damas. Estas mujeres establecieron una red de solidaridad mediante la cual se dedicaban económica, intelectual y socialmente a otras más desfavorecidas. Así, enseñaban a las criadas y a las hijas de éstas a leer y a escribir o prestaban ayuda económica a mujeres sin hogar. En la última etapa de su vida, abandonó la escritura y se dedicó a dirigir una escuela de caridad para hijas de militares retirados del Hospital de Chelsea, que existió hasta 1862. Fue ésta la única realización educativa que Mary Astell pudo llevar a la práctica, ya que su Propuesta no llegó nunca a materializarse. Así, la propia Mary Astell, a la edad de sesenta años, pasó sus últimos años de vida con una de las compañeras de este círculo, Catherine Jones, donde permaneció hasta su muerte en 1731.

De este modo, Mary estuvo convencida toda su vida de que el desarrollo cultural de las mujeres era lo único que les garantizaba la libertad de elección. De este modo, debían convertirse en seres autosuficientes, tanto emocional como intelectualmente, para poder realizar trabajos productivos. El deseo de saber está siempre unido a la felicidad y al goce del conocimiento, todo esto lo expresa en su obra: Una propuesta seria para las damas, en beneficio de sus verdaderos y más altos intereses. Por una amante de su sexo, la primera parte aparecida en 1694 y, la segunda en 1697 , en los cuales da instrucciones a las mujeres sobre cómo pensar de forma clara y lógica. En 1700 publicó Reflexiones sobre el matrimonio, donde reflexiona sobre la unión ocasionada por el duque y la duquesa de Mazarine y en la que condena a los hombres que se casan por dinero, cegados por apetitos irregulares. Por ello, aconseja a las mujeres no casarse simplemente para escapar las dificultades de la vida, sino sólo en base a decisiones muy racionales y meditadas; así, con humor e ironía pone en evidencia las costumbres de la época, que humillan y someten a las mujeres a un matrimonio, que define como una institución tiránica. Asimismo, a lo largo de su prolífica carrera, Mary Astell prestó también atención a temas religiosos y políticos en "Las letras referentes al amor de 
Dios" y "La moderación indicada verdad", en dónde salvaguarda a la iglesia de la época, o en "Una investigación imparcial sobre las causas de la rebelión y de la guerra civil en este reino", en la que defiende los ideales del partido Royalist (1704-1705).

Recientes trabajos como Mary Astell: Theorist of Freedom from Domination (2005) de Patricia Springborg, The Eloquence Of Mary Astell (2006) de Christine Mas o Mary Astell: reason, gender, faith (2007) de William Kolbrener y Michal Michelson, están contribuyendo a que esta prolífera autora alcance el lugar literario que se merece.

3. UNA PROPUESTA SERIA PARA LAS DAMAS, EN BENEFICIO DE SUS VERDADEROS Y MÁS ALTOS INTERESES. POR UNA AMANTE DE SU SEXO.

Mary Astell es una de las figuras fundamentales en cualquier aproximación histórica al pensamiento de las mujeres sobre la educación femenina gracias, principalmente, a su obra $A$ Serious Proposal to the Ladies for the Advancement of their True and Greatest Interest: By a Lover of Her Sex, o en español, Una propuesta seria para las damas, en beneficio de sus verdaderos y más altos intereses. Por una amante de su sexo (1694). Al presentarse la autora como "una amante de su sexo", muestra de forma explícita, ya desde el título, que su propuesta educativa tiene como germen el amor a las mujeres. De hecho, parece que la obra estuviera sólo dirigida a éstas pues, además del pronombre "yo", recurre con frecuencia al pronombre "nosotras" y a la expresión "nuestro sexo".

De este modo, la autora afirma que mientras los hombres gozan de una educación liberal y completa, las mujeres no pueden aspirar a más que a ser "un cero a la izquierda" (Cyphers in the World). Esta expresión sería recogida, años más tarde, por la propia Mary Wollstonecraft en su Vindication of the Rights of Woman (1792). Así, en esta Propuesta, Mary Astell subraya cómo la sociedad se equivoca al no valorar la capacidad de las mujeres y dedicarlas a ser meros objetos de adorno para los hombres desde su más tierna infancia, tal y como refleja el extracto escogido a continuación. La única solución para Mary Astell consistiría en la creación de un seminario de mujeres dedicado a rezar, a leer y a trabajos de caridad. De ahí que King (1993) recogiera la siguiente afirmación de la autora:

¡Feliz Retiro! El que encontraréis cuando entréis en este Paraíso como el que perdió vuestra Madre Eva, donde festejaréis con los Placeres que, al contrario de los de este mundo, no os decepcionarán [...] aquellos que os harán verdaderamente felices ahora, y que os prepararán para que lo seáis perfectamente en el futuro. Aquí no hay Serpientes que os engañen mientras os divertís en estos deliciosos Jardines [...] El lugar al que estáis invitadas es Modelo y Antepasado del Cielo (King, 1993: 291). 
Por consiguiente, Mary Astell concibe su propuesta de seminario como el Paraíso de las mujeres y establece una íntima vinculación entre el conocimiento y la felicidad. Un Paraíso de damas prudentes y piadosas que serían ejemplo e inspiración para otras. El éxito de su Propuesta fue tal que, en el año 1697, apareció una segunda parte, dedicada a la princesa Ana de Dinamarca. En ella, Mary Astell propone con detalle un modelo de aprendizaje y establece modelo de de estudios diseñado para las mujeres deseosas de saber, orientado a lecturas selectas y totalmente alejado del masculino. Desea que la mujer sea capaz de razonar y de desarrollar una metodología de aprendizaje, para lo cual era preciso adquirir conocimientos de lengua, lógica, matemáticas y filosofía. Por consiguiente, como se puede constatar a continuación, el modelo educativo de Mary Astell se aleja de los parámetros establecidos por la conceptualización del saber dominante de su tiempo pues persigue para la mujer un saber generador de libertad.

3.1. Extracto de A Serious Proposal to the Ladies for the Advancement of their True and Greatest Interest: By a Lover of Her Sex (1694)

Women need not take up with mean things, since (if they are not wanting to themselves) they are capable of the best. Neither God nor Nature have excluded them from being Ornaments to their Families and useful in their Generation; there is therefore no reason they should be content to be Cyphers in the World, useless at the best, and in a little time a burden and nuisance to all about them. And 'tis very great pity that they who are so apt to over-rate themselves in smaller matters, shou'd, where it most concerns them to know, and stand upon their Value, be so insensible of their own worth.

The Cause therefore of the defects we labour under, is, if not wholly, yet at least in the first place, to be ascribed to the mistakes of our Education; which like an Error in the first Concoction, spreads its ill Influence through all our Lives.

The Soil is rich and would, if well cultivated, produce a noble Harvest, if then the Unskilful Managers not only permit, but incourage noxious Weeds, tho' we shall suffer by their Neglect, yet they ought not in justice to blame any but themselves, if they reap the Fruit of their own Folly. Women are from their very infancy debarred those Advantages with the want of which they are afterwards reproached, and nursed up in those Vices which will hereafter be upbraided to them. So partial are Men as to expect Brick where they afford no Straw; and so abundantly 
civil as to take care we shou'd make good that obliging Epithet of Ignorant, which out of an excess of good Manners, they are pleas'd to bestow on us!

One would be apt to think indeed, that Parents shou'd take all possible care of their Childrens Education, not only for their sakes, but even for their own. And tho' the Son convey the Name to Posterity, yet certainly a great Part of the Honour of their Families depends on their Daughters. 'Tis the kindness of Education that binds our duty fastest on us: For the being instrumental to the bringing us into the World, is no matter of choice and therefore the less obliging: But to procure that we may live wisely and happily in it, and be capable of endless Joys hereafter, is a benefit we can never sufficiently acknowledge. To introduce poor Children into the World, and neglect to fence them against the temptations of it, and so leave them expos'd to temporal and eternal Miseries, is a wickedness, for which I want a Name; 'tis beneath Brutality; the Beasts are better natur'd for they take care of their off-spring, till they are capable of caring for themselves. And if Mothers had a due regard to their Posterity, how Great soever they are, they wou'd not think themselves too Good to perform what Nature requires, nor thro' Pride and Delicacy remit the poor little one to the care of a Foster Parent. Or, if necessity inforce them to depute another to perform their Duty, they wou'd be as choice at least in the Manners and Inclinations, as they are in the complections of their Nurses, lest with their Milk they transfuse their Vices, and form in the Child such evil habits as will not easily be eradicated.

Nature as bad as it is and as much as it is complain'd of, is so far improveable by the grace of GOD, upon our honest and hearty endeavours, that if we are not wanting to our selves, we mai all in some, tho' not in an equal measure, be instruments of his Glory, Blessings to this World, and capable of eternal Blessedness in that to come. But if our Nature is spoil'd, instead of being improv'd at first; if from our Infancy we are nurs'd up in Ignorance and Vanity; are taught to be Proud and Petulent, Delicate and Fantastick, Humorous and Inconstant, 'tis not strange that the ill effects of this conduct appear in all the future Actions of our Lives. And seeing it is Ignorance, either habitual or or actual, which is the cause of all sin, how are they like to escape this, who are bred up in that? That therefore Women 
are unprofitable to most, and a plague and dishonour to some Men is not much to be regretted on account of the Men, because 'tis the product of their own folly, in denying them the benefits of an ingenuous and liberal Education, the most effectual means to direct them into, and to secure their progress in the way of Vertue.

3.2. Traducción del extracto de A Serious Proposal to the Ladies for the Advancement of their True and Greatest Interest: By a Lover of Her Sex (1694)

Las mujeres no precisan de estar dedicadas a cuestiones banales - si no lo desean-, pues son capaces de todo. $\mathrm{Ni}$ Dios ni la naturaleza las ha excluido de ser ornamentos para sus familias y de utilidad para su generación; por consiguiente, no hay razón por la que debieran contentarse con ser un cero a la izquierda en el mundo, negadas para lo mejor, y en escaso período de tiempo, un fastidio y una carga de todo lo que les concierne. $Y$ es una lástima que ellas, tan propensas a sobrevalorarse en asuntos triviales, deberían, precisamente donde más les compete, reivindicar su valía, les sea tan indiferente su propia capacidad.

Por lo tanto, la causa de los defectos de los que nosotras nos engañamos es, si no totalmente, por lo menos en gran parte, atribuible a los errores de nuestra educación, la cual, como la deglución de un tósigo, se extiende en todo lo concerniente a nuestras vidas.

La tierra es fértil y, si bien cultivada, produciría excelente cosecha, si no fuera porque los inexpertos amos no sólo permiten, sino que abonan las malas hiervas, aunque nosotras suframos por su desabrigo, ellos, en justicia, no deberían culpar a nadie más que a ellos mismos, si recogen el fruto de su propia insensatez. Las mujeres, desde su más tierna infancia, son privadas de aquellas virtudes que, por falta de las cuales serán, en el futuro, criticadas, y amamantadas en aquellos vicios de los que, en lo sucesivo, serán reconvenidas. Los hombres tienen debilidad por esperar recoger frutos cuando no han sembrado, y extremada cortesía en ocuparse de que nosotras cumplamos el provechoso epíteto de ignorante, que a parte de un exceso de buenos modales, ellos están encantados de otorgarnos. 
Podría llegarse a pensar, de hecho, que los padres se ocuparían en todo lo que esté en su mano de la educación de sus hijos, no sólo por el bien de éstos, sino por el de ellos mismos. Y, aunque sea el hijo varón el que transmita el nombre, gran parte del honor de las familias depende de sus hijas. Es la bondad de la educación la que unce nuestro deber prontamente: de ser instrumental a ponernos en el mundo, no es una cuestión de elección y, por consiguiente, menos provechosa; procura que podamos vivir de forma prudente y feliz así, y estar capacitadas para la dicha perpetua en lo sucesivo, por lo que es un bien que nunca podremos agradecer suficientemente. Para incorporar a criaturas pobres en el mundo y no ocuparse de prevenirlas de las tentaciones de éste $y$, por consiguiente, dejándolas expuestas a miserias eternas y temporales, es una maldad para la que quiero un nombre. Se trata de una brutalidad indigna. Las bestias tienen mejor naturaleza pues cuidan de sus crías hasta que son capaces de valerse por sí mismas. Y si las madres tuvieran un deber en lo concerniente a la sucesión, con lo magníficas que son, no se creerían tan excelentes para realizar lo que la naturaleza les pide, pero ni por orgullo y delicadeza dejarían al pequeño ser al cuidado de un padre adoptivo. Bien, si la necesidad vigente las obligara a delegar en otro su deber, sería por elección, al menos en educación, como si ellas estuvieran en la piel de sus cuidadoras, no sea que con su leche mamen sus vicios y formen a la criatura en tal nefastos hábitos que serán difíciles de erradicar.

La naturaleza, tan nociva como criticada, hasta ahora improbable por la gracia de Dios, a pesar de nuestros sinceros esfuerzos, que si no lo queremos para nosotras mismas, podríamos todas ser de la misma, pero no igualitaria manera, instrumentos de su gloria, bendecidas en este mundo y provistas de eterna bendición en todo lo que acontezca. Pero si nuestra naturaleza es amancillada, en vez de mejorada al comienzo y si desde nuestra infancia se nos amamanta en la ignorancia y en la vanidad, se nos enseña a ser orgullosas y petulantes, delicadas y caprichosas, graciosas e inconstantes, no es extraño que los efectos nocivos de esta conducta aparezcan en acciones venideras de nuestras vidas. $Y$ al contemplar su ignorancia, más o menos presente, ¿cuál es la causa de todo pecado?, ¿cómo pueden escapar de esto? Y ¿quién las ha criado así? Por consiguiente, las mujeres son 
inútiles para casi todo, y ser una peste y un deshonor para algunos hombres no es mucho por lo que deban lamentarse, pues es el resultado de su propia insensatez, al denegarles los beneficios de una excelente y liberal educación, la efectiva para garantizarles y conducirlas al camino a la virtud.

\section{CONCLUSION}

Mary Astell, como se puede observar a partir de la lectura de su obra, llevó a cabo una labor de reivindicación del lugar de la mujer en el mundo y su derecho al conocimiento, no por ser feminista, aunque a día de hoy así es considerada, sino por tratarse de una mente brillante en una época en la que era socialmente inaceptable para una mujer pensar $y$, aún más, verbalizar ese pensamiento. Percibió esta injusticia y dedicó su vida a combatirla. Aunque conocía las dificultades de aquella Inglaterra, Mary Astell sabía que contaba con los apoyos necesarios para levantar su escuela femenina y construir un futuro, pero un futuro en igualdad.

\section{REFERENCIAS BIBLIOGRÁFICAS}

ASTELL, Mary, A serious proposal to the ladies, for the advancement of their true and greatest interest. By a lover of her sex. Part 1. London: Richard Wilkin at the King's Head in St. Paul's Church-yard, 1694. , Letters Concerning the Love of God, Between the Author of the Proposal to the Ladies and Mr. John Norris. London: Richard Wilkin at the King's Head in St. Paul's Church-yard, 1695.

for the improvement of their minds. Part 2. London: Richard Wilkin at the King's Head in St. Paul's Church-yard, 1697.

Some Reflections Upon Marriage, Occasion'd by the Duke and Dutchess Mazarine 's Case; which is also considered. NewYork: Source Books, 1700.

, A serious proposal to the ladies, for the advancement of their true and greatest interest. In two parts. By a lover of her sex. London: Richard Wilkin at the King's Head in St. Paul's Church-yard, 1701. A Fair Way with the Dissenters and their Patrons, Not Writ by Mr. L$y$, or any other Furious Jacobite whether Clergyman or Layman; but by a very Moderate Person and Dutiful Subject to the Queen. London: Richard Wilkin at the King's Head in St. Paul's Church-yard, 1704.

, An Impartial Enquiry into the Causes of Rebellion and Civil War in this Kingdom, In an Examination of Dr. Kennett's Sermon Jan. 31, 1703/4. And Vindication of the Royal Martyr. London: Richard Wilkin at the King's Head in St. Paul's Church-yard, 1704. 
Moderation truly Stated: Or, A Review of a Late Pamphlet Entitul'd Moderation a Vertue. With a Prefatory Discourse to D'Avenant, Concerning His Late Essays on Peace and War. London: Richard Wilkin at the King's Head in St. Paul's Church-yard, 1704.

, The Christian Religion, as Profess 'd by a Daughter of the Church of England. London: Richard Wilkin at the King's Head in St. Paul's Church-yard, 1705.

, Bart'lemy Fair Or, An Enquiry after Wit; In which due Respect is had to a Letter Concerning Enthusiasm, To my Lord *** By Mr. Wotton. London: Richard Wilkin at the King's Head in St. Paul's Church-yard, 1709.

Atherton, Margaret, Women Philosophers Of The Early Modern Period. Indianapolis: Hackett Publishing Company, 1994.

Collin, Françoise; Pisier, Evelyne y Varikas, Eleni, Les femmes de Platon à Derrida. Paris: Plon, Anthologie critique, 2000.

KING, Margaret L., Mujeres renacentistas. La búsqueda de un espacio. Madrid, Alianza Universidad, 1993.

KOLBRENER, William y Michelson, Michal, Mary Astell: reason, gender, faith. Ashgate: Burlington, 2007.

LEDUC, Guyonne, "Mary Astell et Daniel Defoe, auteurs de projets féministes pour l'éducation?". En Guyonne Leduc (ed.). L'Éducation des femmes en Europe et en Amérique du Nord de la Renaissance à 1848. Paris: L'Harmattan, 1997.

MARTINO, Giulio; BRUZZESE, Marina, Las filósofas. Las mujeres protagonistas en la historia del pensamiento. Madrid: Cátedra, 1996.

MAson, Christine, The Eloquence Of Mary Astell. Calgary: Sutherland University of Calgary Press, 2006.

MAtTHEWs Grieco, Sara F., "Mary Astell, educadora y feminista". En Giulia Calvi (ed.). La mujer barroca. Madrid: Alianza Editorial, 1995.

SMITH, Florence M., Mary Astell. New York: AMS Press INC., 1966.

SPRINGBORG, Patricia, Mary Astell: Theorist of Freedom from Domination. Cambridge: Cambridge University Press, 2005.

SquADRITO, Kathleen. M., "Mary Astell". En Mary Ellen Waithe (ed). A History of Women Philosophers: Modern Women Philosophers, 16001900. Boston: Kluwer Academic Publishers, 1991.

WollstoneCRAFT, Mary, A Vindication of the Rights of Woman. Boston: Peter Edes, 1792. 